\title{
Multisectoral Initiatives, Sectoral Inertia: A Dilemma of Governance for Development Policy-makers
}

\author{
PERVEZ TAHIR
}

The opinion of development professionals at home and abroad has converged on the point that bad governance lies at the root of the loss of the momentum of economic growth, increasing poverty and failed investment in social sectors. Early concern of development economists with market failure brought in the arguments for the role of government. Government failure was the dominant issue of the eighties. The last decade of the twentieth century is witnessing a focus on governance failure, a broader concept in that the government is not viewed as the only governing entity.

This paper addresses an issue which has been there during the reigns of all these "failure" paradigms. It arises from the inability of governments, organised traditionally into the vertically operating line departments, to deal effectively with multisectoral or cross-sectoral problems and cross-cutting issues. The paper traces the evolution of multisectoral issues and looks at the standard approach of treating multisectoral initiatives as a horizontally fathomed coordination problem to show that it has been an unmitigated disaster. It argues that the multisectoral issues can be better addressed by internalising the elements of coordination, particularly in social sectors, though there have been situations which raise questions about this approach as well.

The large majority of the newly emergent nations of the postwar world adopted a planned course of development, some impressed by the high industrial growth achieved by the Soviet Union and others convinced by the analytical case for overcoming the market imperfections. In both schemes of things, sectors were tightly identified as relating to production, physical infrastructure and social sectors. Industry, agriculture, transport, irrigation, education and health were all sectors, considered autonomously capable of implementing their investment plans and Islamabad.

Pervez Tahir is Joint Chief Economist, The Planning Commission, Government of Pakistan,

Author's Note: Views expressed here are personal and do not necessarily reflect official thinking. 
putting in place the desired policies. In keeping with the popular strategy of the time, the leading sector was industry, supported by physical infrastructure. All else was "planned" to the extent of being allocated the residual resources: the process, the output, i.e., the activities beyond minimal investment input, were left to take care of themselves.

Pakistan's First Five Year Plan [Pakistan (1957)] was no different, despite an exhaustive discussion of key issues of governance for development under the rubric of "public administration". The central argument of the Plan emphasising the "service" aspect of public service, ran like this: the rate of progress of the country is determined not only by the magnitude of resources, but also by the administrative capability. While the administration inherited from the colonial power was reasonably efficient in the collection of revenue, administration of justice and maintenance of law and order, its status quo orientation of "regulating the life of the community" was in conflict with the post-independence requirement of "positive action for promoting (community) welfare". There existed "a fictitious appearance of adequacy for all purposes" which, "on the one hand, creates a psychological atmosphere of complacency unfavourable to reform, and, on the other, increases the inertia of the system, its power of resisting change". Without reform, the Plan warned, "the gulf which existed between the people and the government under foreign rule will not be bridged, and even the basic task of law and order will be confronted with increasing difficulties". ${ }^{1}$

There were only two multisectoral initiatives in the Plan, employment and rural development. The analysis of employment focussed largely on the industrial sector, which held out the promise to overcome underdevelopment. Labour, in effect organised industrial labour, was thus easily treated as a sector. In rural development with village-AID Programme as its flagship, the problem was different. The Plan proposed to place it under the planning agencies to ensure better coordination between line departments/ministries. The principle that the planning agency should not directly administer a development activity was violated. In the absence of a better alternative, the neutrality of the planning agency was sacrificed for the sake of coordination. The Plan stated: "By this means it will be possible to ensure day-today coordination between policy and execution in an activity which is a representative cross-section of the whole field of planned development and from which many lessons likely to be useful in other spheres can be learned".

District administration, an obvious coordination point for rural development, was seen to be oriented towards the colonial priorities of revenue collection, administration of justice and maintenance of law and order. As "the most important link in the long official chain stretching from the villager to the Central Cabinet," the Plan recognised the "large potentialities" of the role of district officer in

${ }^{1}$ The worst fears of the First Plan have been confirmed in the nineties, with the serious deterioration of public order driving down economic and development activity 
development if (a) the orientation changed towards active promotion of development (b) the leadership role in implementation and coordination of development activities in the district was institutionalised and made a counterpart of the inter-departmental coordination at the headquarters and (c) effective supervision and inspection of local government institutions continued. According to the Plan, some counteracting forces were also under operation. These included the deteriorating quality of officers, increasing independence of the development departments and the tendency by these departments to take over the functions and institutions of local governments, particularly the basic services. The Plan maintained that the importance of local government required it to be the subject of a separate provincial department rather than the subordinate part of another department.

In the Second Five Year Plan [Pakistan (1960)], regional development was added to employment and Village AID as a multisectoral initiative. It was, however, no different from employment, a set of activities derived from sectors rather than planned together and as a whole. The Third Five Year Plan [Pakistan (1965)] replaced Village AID Programme with the Rural Works Programme, a multisectoral initiative to mobilise surplus labour for local infrastructure projects. An attempt was also made to plan employment and regional development as programmes rather than sectors. In fact, the Rural Works Programme as well as Regional Development planning had to be made part of the employment and income strategy when it became clear that (a) the direct employment effect of even a plan as successful as the Second Plan in terms of growth made no dent in the backlog of the unemployed, and (b) high growth failed to influence the inter-regional income disparities.

The beginning of this strategic shift also brought into sharper focus the underlying problems of governance. The Village-AID Programme, instead of being placed in the planning agency, had been administered by raising a separate but a temporary organisation. Coordination between the permanent line departments was a serious issue itself. But the coordination between these departments and a temporary organisation like the Village AID organisation led to an enormous waste of time, effort and financial resources. The successor programme, Rural Works Programme, was tested as a pilot by the late Dr Akhtar Hameed Khan at the Comilla Kotawali Thana in 1961. In essence, the pilot demonstrated that the elected Basic Democrats could be trained to resolve, in cooperation with the concerned line departments, the coordination knots involved in the planning and execution of projects of local significance. Basic Democracies were councils of elected and official members at the levels of union, tehsil, district and division. Just as the district was the pivot of colonial administration, so was it made the key unit of development administration by the Provincial Reorganisation Committee set up by the Martial Law regime that took over in October 1958. The difference was that it would entail a degree of public representation. The core function of the district council was to advise and assist the line departments. It was not conceived as the 
basic tier to ensure, in the words of the Second Plan, that "a measure of local programme planning and policy formulation rises upward to the points at which government decisions are taken".

The authors of the Second Plan feared that the "easy course would be simply to continue to do all planning at or near the top of the hierarchy and to use the machinery of Basic Democracies essentially as an instrument for obtaining consent for decisions taken at the Centre and in the Provincial capitals". This easy course was not only adopted but allowed to lay down the foundations of politicisation of development by converting Basic Democrats into an electoral college for the president and the assemblies. The benefits of coordination, proved by the Comilla experiment of [Khan (1975)], failed to develop to scale.

No wonder the Third Plan had to lament: "At the stage of implementation, however, each department tends to concentrate mainly on its own tasks and does not always ensure that its programmes move in step with other related programmes". There were, according to the Plan, "trends observed in certain sectors (e.g., education), where policies adopted militate against the objectives of developing Basic Democracies as vital instruments of local government and relegate them to supporting rather than a leading role". Thus the schools constructed under the Rural Works Programme were not maintained by the education department; they were not part of its programme. Similarly, local educational institutions, which boasted primary school enrolment larger than the education department in the late forties, were being provincialised. Finally the planning, organisation, supervision and overall administrative control of Rural Works Programme rested with the newly created Department of Basic Democracies and Local Government. It succeeded the temporary Village AID Organisation and was in keeping with the First Plan recommendation, noted earlier, to entrust the subject of local government to a separate department. This secretariat was supported by a field organisation, the Directorate of Projects for the Rural Works Programme. Later experience suggested that the inspection and supervision responsibilities entrusted to this department cloaked coercive interference into the affairs of elected bodies when in place and served as an instrument of politicisation of local development whenever these bodies were dismissed arbitrarily.

In sum, the first three five year plans identified rural development in one form or the other as the major multisectoral initiative. In its Village-AID variant, a bikeriding, trained village worker was expected to coordinate the messages of the line departments as a package to be explained to the villagers. The permanent departments themselves were coordinated by the Village AID Organisation, itself a much ignored temporary entity. Coordination was considered a matter of committee meetings or inter-agency cooperation. However, what emerged stronger in the process was the disposition of the line departments to go their separate sectoral ways. In the second variant of rural development, the Rural Works Programme, the aim of 
Dr Akhtar Hameed Khan was to improve rural infrastructure and the productivity of the farmer in an institutional framework whereby his "Thana Training and Development Centres coordinate government departments with councils and cooperatives". Synergies would thus ensue and the whole was expected to be greater than the sum of the parts. In effect the aim turned out to be job creation of the makework variety. The line departments continued to expand and strengthen themselves for large engineering projects. In some cases, the existing departments were broken up into separate entities. Creation of separate departments for multisectoral initiatives, such as the Basic Democracies and the Local Government Department, was only an ill-designed methodology to suppress a multisectoral initiative into a sector-like activity. This happened only to the extent of utilising financial allocation controlled by this new entity. For the rest, the inertia of sectoral departments confronted multisectoral initiatives.

The same story was repeated in the case of subsequent initiatives of People's Works Programme, Five Point Programme, Peoples Programme and Taamer-eWatan Programme. Interestingly, the military governments preferred to implement these programmes through elected local institutions as a way of soliciting a measure of legitimacy for themselves, while the civilian governments looked for alternatives which in most cases established the tyranny of the ministry/department concerned over local government institutions.

During the non-plan period, consumption planning and nutrition also entered the set of multisectoral initiatives. Nutrition to this day has not found a home outside of Planning Commission. The Sixth Plan [Pakistan (1983)] added women development, the Seventh Plan [Pakistan (1988)] poverty alleviation and the Eighth Plan [Pakistan (1994)] placed environment, good governance and Social Action Programme on the expanding multisectoral agenda. The aborted Ninth Plan [Pakistan (1996)] would have contained as many as nine multisectoral initiatives. While some of these, such as women development and environment, have found ministerial homes, others such as poverty alleviation, good governance, nutrition, Social Action Programme (SAP) are subjects dealt with by the Planning Commission.

Environment is, by its very nature, multisectoral and cross-cutting. The authors of the National Conservation Strategy [Pakistan (1992a)] lamented that "the Governmental Rules of Business only adjudicate jurisdiction and do not enforce coordination". The implementation of the (NCS) suffered greatly from turf wars and sectoral exclusionism.

Of all the multisectoral initiatives launched by the government in the past fifty years, none compares with the SAP in terms of size, coverage and the enormity of institutional and governance issues. It involves one sector, population welfare, and three sub-sectors - elementary education, primary health, rural water supply and sanitation. There are three levels of the government to contend with-federal, 
provincial and special areas. Besides the federal government, there are four provinces and four federal areas. The federal areas have their own administrative ministries at the federal level, which are not preferentially disposed towards social sectors. At each level of government the SAP must deal with four line ministries and departments. The so-called policy ministries at the federal level and the implementing departments at the provincial levels need to coordinate with each other for intrasectoral consistency before intersectoral coordination takes place at the level of Planning and Development departments. The country-wide coordination of the SAP rests with the Planning Commission.

A major concern of the SAP is quality enhancement. As the chosen method of addressing this concern is an adequate provision for non-salary component of the recurrent budget, the finance ministry at the federal level and the provincial finance departments add the most exacting dimension of the coordination problem under the SAP.

The cross-cutting decentralisation, gender and poverty alleviation concerns add some more agencies to the coordination maze, as should the objectives of increasing private sector role and greater community participation.

Self-evidently, the SAP in its essence and concept was a programme for improved governance and institutional development and reform. Efficiency, effectiveness, equity, participation, accountability and transparency would be the acid tests for its operations. With donor cooperation, there was an opportunity to turn sectoral inertia into multisectoral dynamism.

In actual operations, however, its first phase set the pace as a programme of investment. There is no doubt that, relative to countries with comparable growth rates and levels of income per capita, Pakistan had neglected to invest in social sectors. But the evidence also suggested that the investment that was made, did not yield the desired quantum and quality of output. Hence the need for reform of governance and institutions. This is where minimum investment would have yielded maximum results. However, the departmental resistance to even procedural reform and the inability of the planning agencies to effectively coordinate anything other than target setting for inputs and mediate departmental struggles for incremental resources, have been the norm rather than the exception. Small wonder, investment increased but output declined in key areas. The unsustainable investment contributed in no small measure to the fiscal crisis of the state.

With allocations expected to be below targets during the second phase of the SAP, the emphasis per force will have to be on improved governance. But there is nothing in the philosophy of the second phase to force the line agencies to see beyond the sectoral nose and the planning agencies to lead the way out of the stiff sectoral joints. The old story of sectoral inertia taking over a multisectoral initiative is ready to repeat. One possible solution may be to abolish the existing SAP-related federal line ministries, which in their present elaborate structures are unconstitutional 
anyway, and create a new Ministry of Human Development. As it will control its allocations as well as the whole sphere of operation, it need not have the problems afflicting other multisectoral ministries like environment and women development.

\section{REFERENCES}

Khan, Akhtar Hameed (1975) The Ghost of Comilla. Integrated Rural Development Review 1:1.

Khan, Akhtar Hameed (1998) Orangi Pilot Project: Reminiscences and Reflections. Karachi: Oxford University Press.

Mahbub ul Haq Human Development Centre (1999) Human Development in South Asia: The Crisis of Governance. Karachi: Oxford University Press.

North, D. (1990) Institutions, Institutional Change and Economic Performance. Cambridge: Cambridge University Press.

Pakistan, Government of (1957) The First Five Year Plan 1955-60. Karachi: National Planning Board.

Pakistan, Government of (1960) The Second Five Year Plan 1960-65. Karachi: Planning Commission.

Pakistan, Government of (1965) The Third Five Year Plan 1965-70. Karachi: Planning Commission.

Pakistan, Government of (1966) The Final Evaluation of the Second Five Year Plan 1960-65. Karachi: Planning Commission.

Pakistan, Government of (1971) Evaluation of the Third Five Year Plan 1965-70. Islamabad: Planning Commission.

Pakistan, Government of (1978) The Fifth Five Year Plan 1978-83. Islamabad: Planning Commission.

Pakistan, Government of (1983) The Sixth Five Year Plan 1983-88. Islamabad: Planning Commission.

Pakistan, Government of (1988) The Seventh Five Year Plan 1988-93. Islamabad: Planning Commission.

Pakistan, Government of (1992) Social Action Programme 1992-95. Islamabad: Planning Commission.

Pakistan, Government of (1992a) The Pakistan National Conservation Strategy. Karachi: Environment and Urban Affairs/IUCN.

Pakistan, Government of (1994) The Eighth Five Year Plan 1993-98. Islamabad: Planning Commission.

Pakistan, Government of (1996) Approach to the Ninth Plan 1998-2003. Islamabad: Planning Commission.

Putnam, R. D. (1993) Making Democracy Work: Civic Traditions in Modern Italy. New Jersey: Princeton University Press.

Qadeer, M. A. (1977) An Evaluation of Integrated Rural Development Programme. Islamabad: Pakistan Institute of Development Economics. 
Social Policy and Development Centre (1999) Social Development in Pakistan: Social Development in Economic Crisis. Karachi: Oxford University Press.

Tahir, Pervez (1999). Poverty Alleviation Policies: A Historical Perspective. In $A$ Profile of Poverty in Pakistan. Islamabad: Mahbubul Haq Human Development Centre. 